\title{
Digital Education of Health Professionals on the Management of Domestic Violence: Systematic Review and Meta-Analysis by the Digital Health Education Collaboration
}

Ushashree Divakar ${ }^{1}, \mathrm{MSc}$; Nuraini Nazeha ${ }^{1}$, BSc; Pawel Posadzki ${ }^{1}, \mathrm{PhD}$; Krister Jarbrink ${ }^{1}, \mathrm{PhD}$; Ram Bajpai ${ }^{1}, \mathrm{PhD}$; Andy Hau Yan $\mathrm{Ho}^{1,2,3}$, PhD, EdD; James Campbell ${ }^{4}$, MSc; Gene Feder ${ }^{5}$, BSc, MBBS, MD, FRCGP; Josip Car ${ }^{1}$, MD, $\mathrm{PhD}$, FRCPE, FFPH

\footnotetext{
${ }^{1}$ Centre for Population Health Sciences, Lee Kong Chian School of Medicine, Nanyang Technological University Singapore, Singapore, Singapore

${ }^{2}$ Psychology Programme, School of Social Sciences, Nanyang Technological University Singapore, Singapore, Singapore

${ }^{3}$ Palliative Care Centre for Excellence in Research and Education, Singapore, Singapore

${ }^{4}$ Department of Health Workforce, World Health Organization, Geneva, Switzerland

${ }^{5}$ School of Social and Community Medicine, University of Bristol, Bristol, United Kingdom
}

\section{Corresponding Author:}

Josip Car, MD, PhD, FRCPE, FFPH

Centre for Population Health Sciences

Lee Kong Chian School of Medicine

Nanyang Technological University Singapore

11 Mandalay Road

Singapore,

Singapore

Phone: 6563402480

Email: josip.car@ntu.edu.sg

\section{Abstract}

Background: The World Health Organization states that $35 \%$ of women experience domestic violence at least once during their lifetimes. However, approximately $80 \%$ of health professionals have never received any training on management of this major public health concern.

Objective: The objective of this study was to evaluate the effectiveness of health professions digital education on domestic violence compared to that of traditional ways or no intervention.

Methods: Seven electronic databases were searched for randomized controlled trials from January 1990 to August 2017 . The Cochrane Handbook guideline was followed, and studies reporting the use of digital education interventions to educate health professionals on domestic violence management were included.

Results: Six studies with 631 participants met our inclusion criteria. Meta-analysis of 5 studies showed that as compared to control conditions, digital education may improve knowledge (510 participants and 5 studies; standardized mean difference [SMD] 0.67, 95\% CI 0.38-0.95; $\mathrm{I}^{2}=59 \%$; low certainty evidence), attitudes (339 participants and 3 studies; SMD 0.67, 95\% CI 0.25-1.09; $\mathrm{I}^{2}=68 \%$; low certainty evidence), and self-efficacy (174 participants and 3 studies; SMD 0.47, 95\% CI 0.16-0.77; $\mathrm{I}^{2}=0 \%$; moderate certainty evidence).

Conclusions: Evidence of the effectiveness of digital education on health professionals' understanding of domestic violence is promising. However, the certainty of the evidence is predominantly low and merits further research. Given the opportunity of scaled transformative digital education, both further research and implementation within an evaluative context should be prioritized.

(J Med Internet Res 2019;21(5):e13868) doi: 10.2196/13868

\section{KEYWORDS}

systematic reviews; evidence-based; health workforce; domestic violence 


\section{Introduction}

Domestic violence (also referred to as family violence) is a complex public health problem [1] that places a notable burden on the health care system [2]. The World Health Organization (WHO) defined domestic violence, an aggressive and oppressive form of interpersonal violence, as a situation where an individual uses control tactics to emotionally, physically, sexually, or economically abuse a family member or past/current romantic partner [3]. Forms of control behavior can include but are not limited to psychological, physical, sexual, financial, and emotional abuse [4].

The WHO commissioned a multinational study on domestic violence with data collected from 10 countries, which showed that $13 \%-61 \%$ of women between the ages of $15-49$ years had experienced physical abuse from their intimate partners at least once in their lifetime [3]. However, due to various reasons including shame, embarrassment, social stigma, and fear of and dependency on the abuser, survivors are often unwilling to reveal their difficulties to others [5,6]. Domestic violence can have both short- and long-term effects on the mental and physical well-being of the survivors. Injuries and physical ailments resulting from prolonged exposure to domestic violence include chronic neurological disorders, cardiovascular diseases, respiratory, intestinal and digestive conditions, reproductive disorders, physical injuries, and even death [7-10]. The less visible, but equally detrimental, impact of domestic violence includes psychological and emotional sufferings, anxiety, fear, depression, and posttraumatic stress [11]. Survivors often require treatment and care from a spectrum of health professionals, ranging from family physicians to physical therapists or clinical psychologists [5].

By facilitating early detection and treatment through a well-structured system of education and support, health professionals could play an important role in promoting greater awareness on domestic violence, identifying survivors of violence, and enabling survivor protection [12]. As health professionals are usually the first line of contact for survivors, they would need to undergo special training to identify, support, and treat domestic violence patients. This would be of particular importance to conservative societies where domestic violence is known to be severely underreported $[13,14]$. Moreover, the immense shortage of health professionals worldwide, especially in developing countries [15], compounded by the lack of training of health professionals, poses immense challenges in tackling the global domestic violence crisis $[13,16]$.

Occasional training programs on domestic violence consisting of seminars and workshops often claim poor retention rates, as they are mostly time-consuming [17], require health professionals to travel to training locations, and are taught by academics who themselves may have had little exposure to people who have experienced domestic violence $[18,19]$. With the increasing use of information communication technologies in health professions' education, leveraging on digital education to provide domestic violence management education could help address the various challenges of training and manpower shortage while improving the cost-effectiveness of educational programs [20-22].

The term digital education refers to a range of teaching and learning strategies that utilize digital media and devices for training and as interaction tools [23]. Digital education can be further subclassified into various types according to delivery methods (online or offline), content, learning objectives, pedagogical approaches, and delivery settings [24]. The use of the internet to deliver content is referred to as the online mode of digital education, while the use of software or PowerPoint without the need for the internet to deliver content is referred to as the offline mode of digital education. With its scalability, flexibility, cost-effectiveness, and ability to overcome geographical and temporal constraints, digital education has the potential to provide more independent, customized, and accessible domestic violence training. Studies comparing digital education to traditional methods in various specialties including medical education and engineering have found digital education to be more efficient and effective in building knowledge $[25,26]$.

Although a previous study reviewed domestic violence education among health professionals [19], digital education has been gaining popularity in health professions' curricula and hence its use in domestic violence education should be studied further. To the best of our knowledge, there are no systematic reviews evaluating the effectiveness of digital health interventions specifically for domestic violence training among health professionals. Hence, the objective of this study was to evaluate the effectiveness of health professions' digital education on domestic violence compared to that of traditional ways or no intervention.

\section{Methods}

\section{Search Strategy}

We followed the Cochrane Handbook guidelines for this review. A more detailed description of the methodology is provided in the paper by Car et al [27]. This review is part of a global evidence-synthesis initiative for digital health professions' education [28-39]. The search for the relevant trials was conducted across 7 databases: MEDLINE (Ovid), EMBASE (Elsevier), the Cochrane Central Register of Controlled Trials (Wiley), PsychINFO (Ovid), Educational Resource Information Centre (Ovid), Cumulative Index to Nursing and Allied Health Literature (EBSCO), and Web of Science Core Collection (Thomson Reuters). The detailed search strategy for MEDLINE is presented in the Multimedia Appendix 1. A manual search was conducted to identify any relevant articles from the reference lists of all included articles. A search was also conducted in the International Clinical Trials Registry Platform Search Portal and the metaRegister of Controlled Trials to identify unpublished trials, meeting abstracts, and doctoral theses from Jan 1990 to August 2017.

\section{Eligibility Criteria}

The inclusion criteria are presented in Textbox 1. We adopted a broad definition of domestic violence, encompassing all subcategories of domestic violence, to capture a wide range of studies on the topic. 
Textbox 1. Inclusion criteria for studies.

Design

- $\quad$ Randomized controlled trials

- Cluster randomized controlled trials

Participants

- Preregistration undergraduates enrolled in health-related courses (including allied health, nursing, and rehabilitation specialization).

- Preregistration undergraduate education or basic vocational training is defined as any type of study leading to a qualification that (1) is recognized by the relevant government or professional bodies of the country where the study was conducted and (2) entitles the qualification holder to apply for entry-level positions in the health care workforce or have direct contact with patients

- Postregistration health professionals undertaking Continued Medical Education and Continued Professional Development.

- Postregistration is defined as any type of qualification that is recognized by the relevant government bodies and enables the holder to gain entry into or continue to work in the health care workforce in a more independent or senior role, excluding traditional/complementary medicine practitioners

- Continued Medical Education is defined as "educational activities which serve to maintain, develop, or increase the knowledge, skills, and professional performance and relationships that a health professional uses to provide services for patients, the public, or the profession" [41]

- Continued Professional Development is defined as "a range of learning activities through which health and care professionals maintain and develop throughout their career to ensure that they retain their capacity to practice safely, effectively and legally within their evolving scope of practice" [42]

Interventions/exposure

- Studies that use digital education interventions to train pre- and postregistration health professionals in domestic violence management

- Training is delivered via digital education alone (fully) or partially (ie, blended learning)

Comparator(s)/control

- Studies comparing digital education interventions with traditional methods of learning domestic violence management

- Studies comparing digital education interventions with control groups that do not receive any training on domestic violence management

- Studies comparing one type of digital education intervention to another

Outcomes

- $\quad$ Primary outcomes (assessed using validated or nonvalidated measurement tools):

- Learners' knowledge postintervention

- Learners' skills postintervention

- Learners' attitudes

- Learners' improvement of self-efficacy defined as improved efficiency toward domestic violence management

- Secondary outcomes (assessed using validated or nonvalidated measurement tools):

- Learners' satisfaction postintervention

- Patient-related outcomes

- Cost and cost-effectiveness of the intervention

- Any adverse or unintended effects of digital education interventions

Timeline

- Publications from January 1990 through August 2017

We included randomized controlled trials (RCTs) and quasi-randomized trials reporting the use of digital education interventions (including blended learning, which is a combination of conventional learning and digital education) to educate health professionals on domestic violence management.
RCTs with and without control groups that received traditional interventions delivered by either health professionals or university personnel were included. Studies targeting both practicing health professionals and students were included in this review. No language restrictions were imposed. All digital 
education interventions were included. Cross-over studies were excluded due to the high likelihood of carry-over effects [40]. Non-RCTs and studies not focusing on computer-based interventions and interventions delivered to individuals other than health professionals were also excluded.

\section{Study Selection}

The search results from all the databases were combined in a single Endnote X8 library (Clarivate Analytics, Philadelphia, PA), and all duplicate records were removed. Search filters were used to remove articles not related to digital education for health professionals. Two reviewers (UD and NN) then independently screened the titles, abstracts, and full-text articles to identify studies potentially meeting the inclusion criteria. Disagreements were resolved through discussion between the reviewers. Primary outcomes included knowledge, skills, attitudes, self-efficacy, and satisfaction with the education measured using any validated and nonvalidated instruments. Secondary outcome measures included patient outcomes (eg, feedback from domestic violence survivors seeking treatment), change in health professionals' behavior (ie, health professionals' confidence in and ease of identifying and treating domestic violence survivors), and economic impact of the intervention.

\section{Data Extraction}

All the relevant data including study characteristics, type of digital education intervention, participant demographics, data for outcome measures, and other publication details were extracted independently by UD and NN using a structured data extraction form. We contacted one study author (Short LM) [43] for missing information.

\section{Risk of Bias Assessment and the Overall Quality of Evidence}

UD and NN independently assessed the risk of bias using the Cochrane Collaboration's risk of bias tool [44]. When it was unclear if a trial was of low or high risk, the field was coded as unclear risk of bias. The following domains were evaluated: random sequence generation, allocation concealment, blinding of participants and personnel, blinding of outcome assessors, incomplete outcome data, selective outcome reporting, and other bias. The following GRADE (Grading of Recommendations Assessment, Development and Evaluation) criteria for evaluating the overall quality of evidence were used: limitations of studies (risk of bias), inconsistency (heterogeneity), indirectness, imprecision, and publication bias [45].

\section{Data Synthesis}

Postintervention mean and SDs were used. The baseline mean value was used to calculate the final posttest mean and SD in studies that presented change scores rather than the final mean. When the studies compared more than two groups, the results from the comparison of the least active control group and the most active intervention group were presented.

\section{Statistical Analysis}

We pooled the data using the random-effect model and calculated standardized mean differences (SMDs) with 95\% CIs. Statistical heterogeneity across studies was assessed using the Cochran Q test and $\mathrm{I}^{2}$ statistics (negligible: 0\%-40\%, moderate: $30 \%-60 \%$, or substantial: $50 \%-90 \%$ heterogeneity) [44]. All statistical analyses were conducted using RevMan software (version 5.3; The Nordic Cochrane Centre, Copenhagen, Denmark).

\section{Results}

The searches generated a total of 30,073 references. Following abstract and title screening, 144 articles were found to be relevant to domestic violence and selected for full-text screening. Of those, six met our eligibility criteria (Figure 1). 
Figure 1. Preferred Reported Items for Systematic Reviews and Meta-analyses chart summarizing the selection process. RCT: randomized controlled trial.

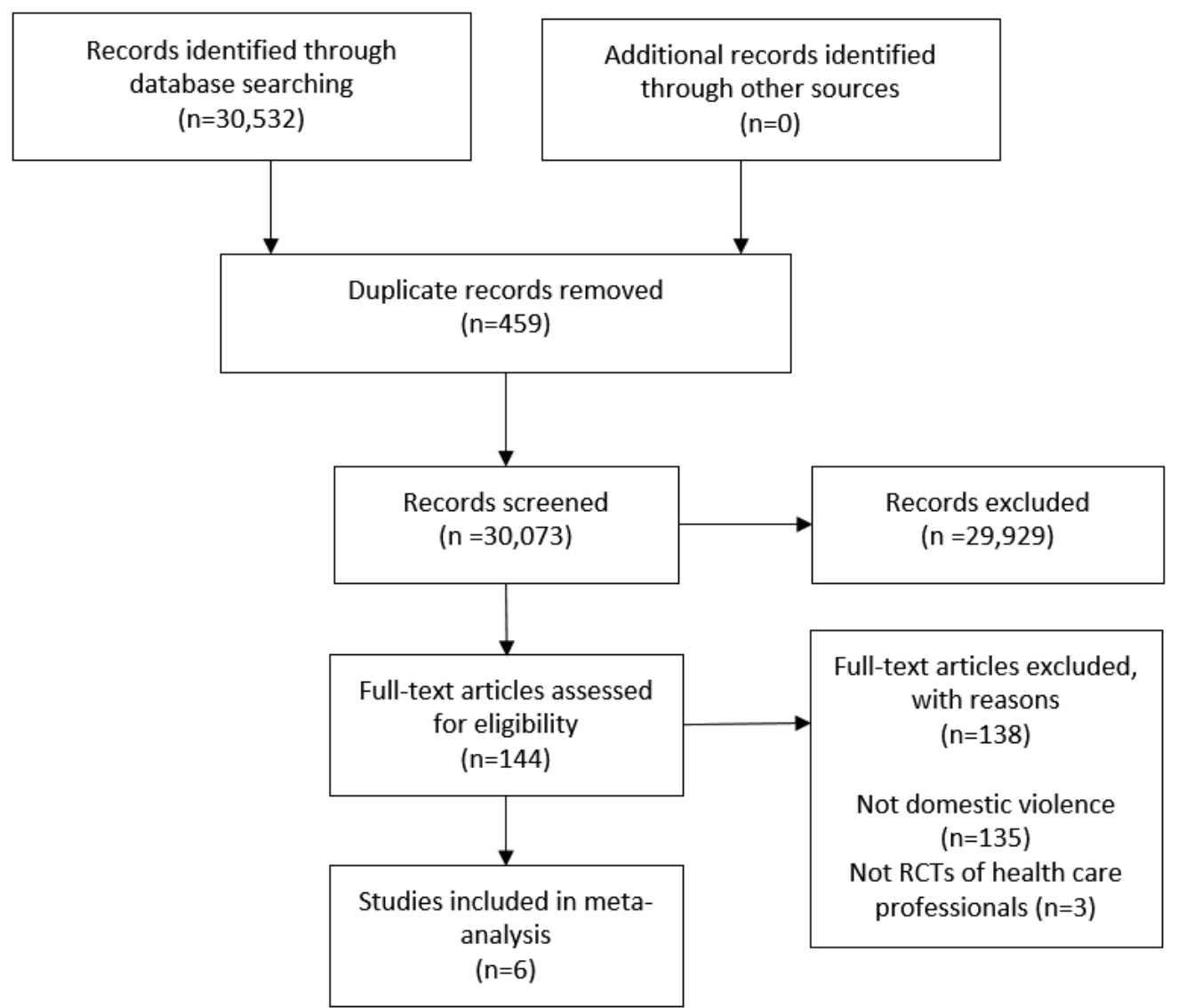

\section{Study Characteristics}

All the 6 included RCTs were published between 2000 and 2014 in high-income countries: 5 were from the United States [43,46-49] and 1 was from the Netherlands [50]. All the studies included were parallel RCTs. Three of the studies were conducted in a university setting, and the remaining three were conducted in community and hospital settings. Two of the studies $[49,50]$ focused on child abuse; one, on intimate partner violence [43], and three, on domestic violence, in general [46-48]. In addition, three studies targeted dental professionals $[46,48,49]$, two targeted physicians $[43,47]$, and one targeted nurses [50].
A total of 631 participants were included in the six studies, of which 420 participants $(66 \%)$ were dentists and dental students. Three studies used offline and three studies used online modes of delivering digital education intervention. The following primary outcomes were reported: knowledge [43,46-49], attitudes [43,46-48], self-efficacy [43,47,50], and skills [50]. Surveys, questionnaires, and checklist were used to measure these outcomes, of which only two instruments $[43,47]$ were validated. The duration of the intervention varied between 15 minutes and 3 weeks. Tables 1 and 2 summarize the main characteristics of the included studies. The study by Shapiro [49], including second-year dental students, on recognizing child abuse was the only study comparing a digital education intervention with traditional lecture-based learning, whereas all the other studies compared digital education to no intervention. 
Table 1. Characteristics of the included studies.

\begin{tabular}{|c|c|c|c|c|}
\hline $\begin{array}{l}\text { Study (year), country, } \\
\text { setting }\end{array}$ & $\begin{array}{l}\text { Characteristics of partici- } \\
\text { pants } \\
\text { (preregistration/postregis- } \\
\text { tration/mixed) and field } \\
\text { of study (number of par- } \\
\text { ticipants) }\end{array}$ & Intervention (duration) & Control & Results \\
\hline $\begin{array}{l}\text { Danley et al (2004), } \\
\text { USA, university [46] }\end{array}$ & $\begin{array}{l}\text { Mixed (dental students } \\
\text { and dentists); dentistry } \\
(\mathrm{N}=174)\end{array}$ & $\begin{array}{l}\text { Offline interactive multimedia tuto- } \\
\text { rial on } \mathrm{DV}^{\mathrm{a}} \text { designed to educate } \\
\text { dentists to identify and respond to } \\
\text { DV. Control group had no interven- } \\
\text { tion. Assessment via questionnaires } \\
\text { (15-25 min) }\end{array}$ & No intervention & $\begin{array}{l}\text { Intervention demonstrated signifi- } \\
\text { cantly improved attitudes and } \\
\text { knowledge compared to the control } \\
\text { group. }\end{array}$ \\
\hline $\begin{array}{l}\text { Harris et al (2002), USA, } \\
\text { medical association [47] }\end{array}$ & $\begin{array}{l}\text { Postregistration (physi- } \\
\text { cians); primary care, } \\
\text { emergency medicine, and } \\
\text { orthopedics }(\mathrm{N}=121)\end{array}$ & $\begin{array}{l}\text { Online DV program designed to } \\
\text { improve the confidence of practic- } \\
\text { ing physicians in managing DV pa- } \\
\text { tients. Assessment via question- } \\
\text { naires ( } 2 \text { weeks to complete the } \\
\text { program) }\end{array}$ & No intervention & $\begin{array}{l}\text { Online education program on DV } \\
\text { can improve physician confidence } \\
\text { (measured by self-efficacy), atti- } \\
\text { tudes, and self-reported knowledge } \\
\text { in managing DV patients. In addi- } \\
\text { tion, } 17.8 \% \text { mean change in the self- } \\
\text { efficacy domain score for the inter- } \\
\text { vention group versus }-0.6 \% \text { change } \\
\text { for the control group ( } P<.001 \text { ) was } \\
\text { observed. Self-reported user satisfac- } \\
\text { tion with the program was high. }\end{array}$ \\
\hline $\begin{array}{l}\text { Hsieh et al (2006), USA, } \\
\text { university and clinics } \\
{[48]}\end{array}$ & $\begin{array}{l}\text { Postregistration (den- } \\
\text { tists); dentistry }(\mathrm{N}=174)\end{array}$ & $\begin{array}{l}\text { Offline interactive multimedia tuto- } \\
\text { rial on DV designed to educate } \\
\text { dentists to identify and respond to } \\
\text { DV. Assessment via questionnaires } \\
\text { (15 min) }\end{array}$ & No intervention & $\begin{array}{l}\text { The posttest comparison of the two } \\
\text { groups was statistically significant } \\
(P=.01) \text { in favor of the online train- } \\
\text { ing group. }\end{array}$ \\
\hline $\begin{array}{l}\text { Shapiro et al (2014), } \\
\text { USA, university [49] }\end{array}$ & $\begin{array}{l}\text { Preregistration (dental } \\
\text { students); dentistry } \\
(\mathrm{N}=72)\end{array}$ & $\begin{array}{l}\text { Online interactive training module } \\
\text { to educate dental students on child } \\
\text { abuse, assessed via questionnaires } \\
\text { ( } 3 \text { weeks for reviewing the online } \\
\text { module) }\end{array}$ & $\begin{array}{l}\text { Traditional lecture- } \\
\text { based session }\end{array}$ & $\begin{array}{l}\text { In } \mathrm{LG}^{\mathrm{b}}, 91.6 \% \text { agreed or strongly } \\
\text { agreed that the traditional lecture } \\
\text { was a good way to learn the materi- } \\
\text { al. }\end{array}$ \\
\hline $\begin{array}{l}\text { Short et al (2006), USA, } \\
\text { community practice [43] }\end{array}$ & $\begin{array}{l}\text { Postregistration (commu- } \\
\text { nity physicians); family } \\
\text { medicine, pediatrics, ob- } \\
\text { stetrics, and gynecology } \\
(\mathrm{N}=52)\end{array}$ & $\begin{array}{l}\text { Online } \mathrm{CME}^{\mathrm{c}} \text { program to educate } \\
\mathrm{HCPs}^{\mathrm{d}} \text { on IPV } \mathrm{IP}^{\mathrm{e}} \text { program in a com- } \\
\text { munity practice setting assessed via } \\
\text { self-administered, paper-based sur- } \\
\text { vey tool (minimum } 4 \text { hours) }\end{array}$ & No intervention & $\begin{array}{l}\text { Online } \mathrm{CME}^{\mathrm{f}} \text { survey program for } \\
\text { physician readiness to manage inti- } \\
\text { mate partner violence was success- } \\
\text { ful in improving physicians' IPV } \\
\text { knowledge, attitudes, and self-effi- } \\
\text { cacy. }\end{array}$ \\
\hline $\begin{array}{l}\text { Smeekens et al (2011), } \\
\text { The Netherlands, medical } \\
\text { center [50] }\end{array}$ & $\begin{array}{l}\text { Postregistration (nurses); } \\
\text { emergency medicine } \\
(\mathrm{N}=38)\end{array}$ & $\begin{array}{l}\text { Offline program designed to educate } \\
\text { nurses to recognize child abuse in a } \\
\text { simulated case, assessed via perfor- } \\
\text { mance in simulated cases (minimum } \\
\text { of } 2 \text { hours during a } 2 \text {-week period) }\end{array}$ & No intervention & $\begin{array}{l}\text { Nurses in the intervention group } \\
\text { performed significantly better dur- } \\
\text { ing the simulation than the control } \\
\text { group and reported higher self-effi- } \\
\text { cacy. }\end{array}$ \\
\hline
\end{tabular}

${ }^{\mathrm{a} D V}$ : domestic violence.

${ }^{\mathrm{b}} \mathrm{LG}$ : lecture group

${ }^{\mathrm{c}} \mathrm{CME}$ : Continued Medical Education.

${ }^{\mathrm{d}} \mathrm{HCP}$ : health care professional.

${ }^{\mathrm{e}} \mathrm{IPV}$ : intimate partner violence.

${ }^{\mathrm{f}}$ Continued Medical Education is defined as "educational activities which serve to maintain, develop, or increase the knowledge, skills, and professional performance and relationships that a health professional uses to provide services for patients, the public, or the profession" [48]. 
Table 2. Outcomes of the included studies.

\begin{tabular}{|c|c|c|}
\hline Study and outcome measures & Intervention group score, mean (SD) & Control group score, mean (SD) \\
\hline \multicolumn{3}{|l|}{ Danley et al [46] } \\
\hline Knowledge & $3.0(0.76)$ & $2.1(0.78)$ \\
\hline Attitude & $4.6(1.15)$ & $3.9(1.08)$ \\
\hline \multicolumn{3}{|l|}{ Harris et al [47] } \\
\hline Knowledge & $3.3(1.96)$ & $2.5(0.02)$ \\
\hline Attitude & $-^{\mathrm{a}}$ & - \\
\hline Satisfaction & - & - \\
\hline Self-efficacy & $3.7(1.20)$ & $3.3(0.04)$ \\
\hline \multicolumn{3}{|l|}{ Hsieh et al [48] } \\
\hline Knowledge & $3.1(2.29)$ & $2.3(0.18)$ \\
\hline Attitude & $5.5(0.19)$ & $4.8(1.25)$ \\
\hline \multicolumn{3}{|l|}{ Shapiro et al [49] } \\
\hline Knowledge & $80.5(1.24)$ & $76.1(1.56)$ \\
\hline Satisfaction & - & - \\
\hline \multicolumn{3}{|l|}{ Short et al [43] } \\
\hline Knowledge & $28.4(5.68)$ & $25.8(5.68)$ \\
\hline Attitude & $4.7(1.00)$ & $3.5(1.00)$ \\
\hline Self-efficacy & $4.6(1.15)$ & $3.8(1.15)$ \\
\hline \multicolumn{3}{|l|}{ Smeekens et al [50] } \\
\hline Skills & $71(18)$ & $89(19)$ \\
\hline Self-efficacy & 447 (98) & $502(96)$ \\
\hline
\end{tabular}

${ }^{\mathrm{a}}$ Not available.

\section{Effects of Interventions}

Meta-analysis of five studies [43,46-49] considered to be sufficiently homogeneous found that digital education (offline and online) may increase knowledge of domestic violence in dentists, physicians, and allied health professionals (510 participants; SMD 0.67, 95\% CI 0.38-0.95; $\mathrm{I}^{2}=59 \%$; low certainty evidence) compared with no intervention and traditional learning postintervention. There was evidence of moderate heterogeneity among the studies $\left(\zeta^{2}=0.06 ; \chi^{2}{ }_{4}=9.7\right.$; $P=.05 ; \mathrm{I}^{2}=59 \%$; Figure 2).

Meta-analysis of three studies $[43,46,48]$ found that compared to no intervention, digital education (offline and online) may increase postintervention attitude toward domestic violence management in dentists and physicians (339 participants; SMD
$0.67,95 \%$ CI $\left.0.25-1.09 ; \mathrm{I}^{2}=68 \%\right)$. There was a substantial level of heterogeneity among the studies $\left(\zeta^{2}=0.09 ; \chi^{2}{ }_{2}=6.3 ; P=.04\right.$; $\mathrm{I}^{2}=68 \%$ ).

Meta-analysis of three studies $[43,47,50]$ found that compared to no intervention, digital education (offline and online) may increase postintervention self-efficacy toward domestic violence management in physicians and nurses (174 participants; SMD $0.47,95 \%$ CI $\left.0.16-0.77 ; \mathrm{I}^{2}=0 \%\right)$. The was no evidence of heterogeneity $\left(\zeta^{2}=0.00 ; \chi^{2}{ }_{2}=0.7 ; P=.71 ; \mathrm{I}^{2}=0 \%\right)$.

One study [50] comparing change of score in skills found that digital education (offline program) may improve domestic violence skills in nurses (25 participants; SMD 0.94, 95\% CI 0.11-1.77) compared to no intervention. 
Figure 2. Forest plot comparing the experimental and control groups in terms of outcomes. IV: interval variable; random: random effect model; std: standardized.

\begin{tabular}{|c|c|c|c|c|c|c|c|c|c|}
\hline \multirow[b]{2}{*}{ Study or Subgroup } & \multicolumn{3}{|c|}{ Experimental } & \multicolumn{3}{|c|}{ Control } & \multicolumn{2}{|c|}{ Std. Mean Difference } & \multirow{2}{*}{$\begin{array}{l}\text { Std. Mean Difference } \\
\text { IV, Random, } 95 \% \mathrm{CI}\end{array}$} \\
\hline & Mean & SD & Total & Mean & SD & Total & Weight & IV, Random, $95 \% \mathrm{Cl}$ & \\
\hline \multicolumn{10}{|l|}{ 1.1.1 Knowledge } \\
\hline Danley 2004 & 3.08 & 0.76 & 56 & 2.13 & 0.78 & 59 & $20.9 \%$ & $1.23[0.83,1.62]$ & \\
\hline Harris 2002 & 3.31 & 1.96 & 50 & 2.51 & 0.02 & 49 & $20.8 \%$ & $0.57[0.17,0.97]$ & \\
\hline Hsieh 2006 & 3.13 & 2.29 & 86 & 2.3 & 0.18 & 88 & $25.2 \%$ & $0.51[0.21,0.81]$ & \\
\hline Shapiro 2014 & 80.6 & 7.44 & 36 & 76.1 & 9.36 & 36 & $18.1 \%$ & $0.53[0.06,1.00]$ & \\
\hline Short 2006 & 28.46 & 5.69 & 22 & 25.89 & 5.68 & 28 & $14.9 \%$ & $0.45[-0.12,1.01]$ & \\
\hline \multicolumn{10}{|c|}{$\begin{array}{l}\text { Heterogeneity: } \operatorname{Tau}^{2}=0.06 ; \mathrm{Chi}^{2}=9.66, \mathrm{df}=4(P=0.05) ; I^{2}=59 \% \\
\text { Test for overall effect: } Z=4.52(P<0.00001)\end{array}$} \\
\hline \multicolumn{10}{|l|}{ 1.1.2 Attitude } \\
\hline Danley 2004 & 4.68 & 1.15 & 56 & 3.93 & 1.08 & 59 & $35.7 \%$ & $0.67[0.29,1.04]$ & \\
\hline Hsieh 2006. & 5.5 & 2.5 & 86 & 4.88 & 0.39 & 88 & $39.9 \%$ & $0.35[0.05,0.65]$ & \\
\hline $\begin{array}{l}\text { Short } 2006 \\
\text { Subtotal }(95 \% \mathrm{Cl})\end{array}$ & 4.7 & 0.99 & $\begin{array}{r}22 \\
164\end{array}$ & 3.5 & 1 & $\begin{array}{r}28 \\
175\end{array}$ & $\begin{array}{r}24.4 \% \\
100.0 \%\end{array}$ & $\begin{array}{l}1.19[0.58,1.80] \\
0.67[0.25,1.09]\end{array}$ & \\
\hline \multicolumn{10}{|c|}{$\begin{array}{l}\text { Heterogeneity: } \mathrm{Tau}^{2}=0.09 ; \mathrm{Ch}^{2}=6.33, \mathrm{df}=2(\mathrm{P}=0.04) ; \mathrm{I}^{2}=68 \% \\
\text { Test for overall effect: } Z=3.11(P=0.002)\end{array}$} \\
\hline \multicolumn{10}{|l|}{ 1.1.3 Self-efficacy } \\
\hline Harris 2002 & 3.7 & 1.2 & 50 & 3.39 & 0.04 & 49 & $58.0 \%$ & $0.36[-0.04,0.76]$ & \\
\hline Short 2006 & 4.64 & 1.15 & 22 & 3.89 & 1.15 & 28 & $27.8 \%$ & $0.64[0.07,1.22]$ & \\
\hline $\begin{array}{l}\text { Smeekens } 2011 \\
\text { Subtotal }(95 \% \mathrm{Cl})\end{array}$ & 502 & 96 & $\begin{array}{l}13 \\
85\end{array}$ & 447 & 98 & $\begin{array}{l}12 \\
89\end{array}$ & $\begin{array}{r}14.2 \% \\
100.0 \%\end{array}$ & $\begin{array}{l}0.55[-0.25,1.35] \\
0.47[0.16,0.77]\end{array}$ & \\
\hline \multicolumn{10}{|c|}{$\begin{array}{l}\text { Heterogeneity: } \mathrm{Tau}^{2}=0.00 ; \mathrm{Chi}^{2}=0.67, \mathrm{df}=2(\mathrm{P}=0.71) ; \mathrm{I}^{2}=0 \% \\
\text { Test for overall effect: } Z=3.02(P=0.003)\end{array}$} \\
\hline \multicolumn{10}{|l|}{ 1.1.4 Skills } \\
\hline $\begin{array}{l}\text { Smeekens } 2011 \\
\text { Subtotal }(95 \% \mathrm{Cl})\end{array}$ & 89 & 19 & $\begin{array}{l}13 \\
13\end{array}$ & 71 & 18 & $\begin{array}{l}12 \\
12\end{array}$ & $\begin{array}{l}100.0 \% \\
100.0 \%\end{array}$ & $\begin{array}{l}0.94[0.11,1.77] \\
0.94[0.11,1.77]\end{array}$ & \\
\hline \multicolumn{10}{|c|}{$\begin{array}{l}\text { Heterogeneity: Not applicable } \\
\text { Test for overall effect: } Z=2.21(P=0.03)\end{array}$} \\
\hline
\end{tabular}

\section{Summary Risk of Bias}

Of the six studies, four $[43,46,48,50]$ were found to have an overall low risk of bias and the remaining two [47,49] had a high or an unclear risk of bias.

The random sequence generation method was reported in four $[43,46,48,50]$ of the six studies. Blinding and protection against selective reporting was achieved through the nature of the intervention and the reporting of all the results in all the studies. Attrition and other biases were of low risk for five [43,46,48-50]

of the six studies. One study had a high risk of attrition bias resulting from a high drop-out rate $(42 \%)$. However, details of allocation concealment were not reported in any of the studies, and blinding of outcome assessment was attempted in only one study [50]. Similarly, the method for random sequence generation was not clearly stated in two studies [47,49]. At the individual-study level, of 56 domains, 14 (25\%) were reported as unclear and one (2\%) was reported as high risk (Figure 3 ). The summary of findings table shows the evidence to be of low to moderate quality as analyzed per the GRADE criteria (Table $3)$. 
Figure 3. Risk of bias summary.

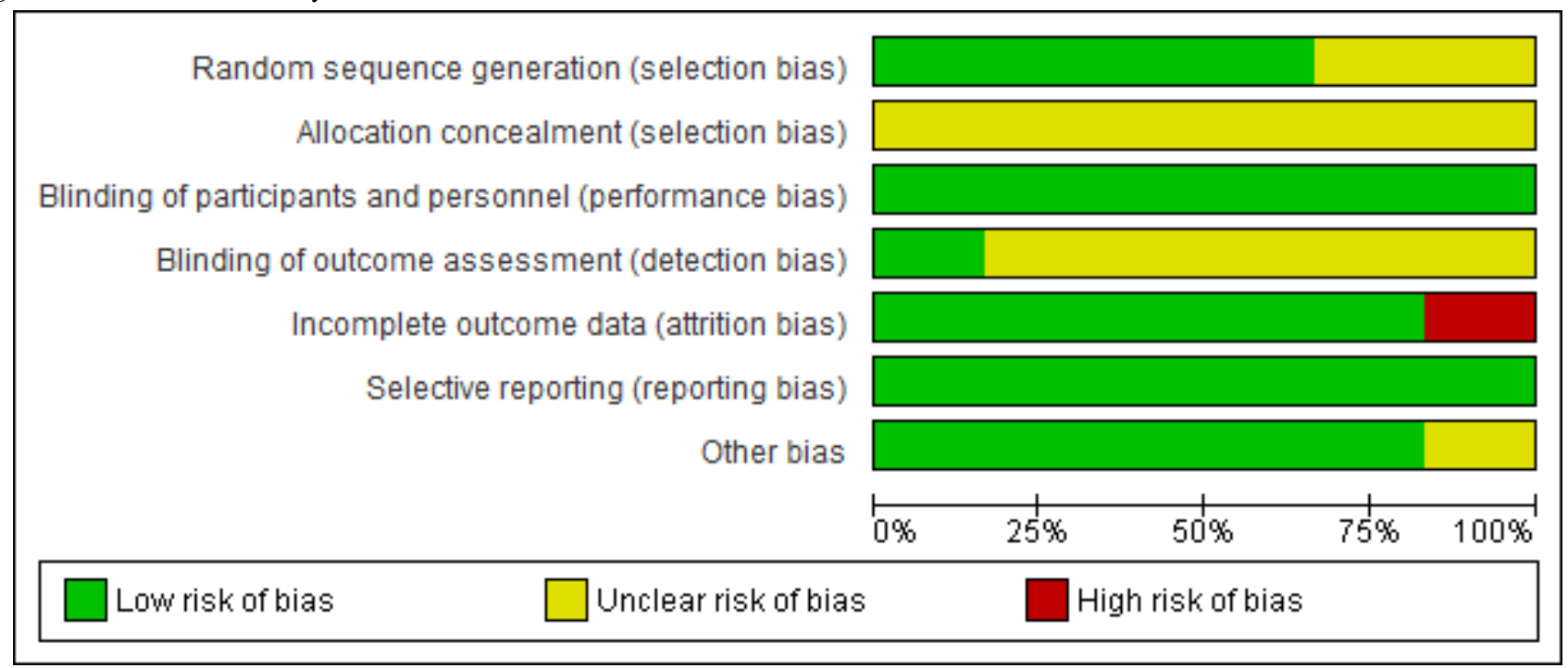

Table 3. Summary of findings table. Patient or population: health care professionals; Setting: university; Intervention: digital education; Comparison: traditional or no intervention.

\begin{tabular}{|c|c|c|c|c|c|}
\hline \multirow[t]{2}{*}{ Outcomes } & \multicolumn{2}{|c|}{ Anticipated absolute effects ${ }^{\mathrm{a}}(95 \% \mathrm{CI})$} & \multirow{2}{*}{$\begin{array}{l}\text { Number of partici- } \\
\text { pants (number of } \\
\text { RCTs }^{\text {b }} \text { ) }\end{array}$} & \multirow{2}{*}{$\begin{array}{l}\text { Certainty of the evi- } \\
\text { dence }\left(\mathrm{GRADE}^{\mathrm{c}} \text { ) }\right.\end{array}$} & \multirow[t]{2}{*}{ Comments } \\
\hline & Assumed risk with controls & $\begin{array}{l}\text { Corresponding risk with } \\
\text { electronic learning }\end{array}$ & & & \\
\hline Knowledge & $\begin{array}{l}\text { The mean outcome score in } \\
\text { the control groups was } 21.79\end{array}$ & $\begin{array}{l}\text { The mean knowledge score } \\
\text { in the intervention groups } \\
\text { was } 0.67 \text { SD higher }(0.38- \\
0.95 \text { higher })\end{array}$ & $510(5)$ & Low $^{\mathrm{d}, \mathrm{e}, \mathrm{f}}$ & None \\
\hline Attitude & $\begin{array}{l}\text { The mean outcome score in } \\
\text { the control groups was } 4.10\end{array}$ & $\begin{array}{l}\text { The mean attitude score in } \\
\text { the intervention groups was } \\
0.67 \text { SD higher }(0.25-1.09 \\
\text { higher) }\end{array}$ & $339(3)$ & Low $^{\text {d,e,f }}$ & $\begin{array}{l}\text { The results of one study } \\
\text { ( } 121 \text { participants) were not } \\
\text { pooled due to incomplete } \\
\text { data }\end{array}$ \\
\hline Self-efficacy & $\begin{array}{l}\text { The mean outcome score in } \\
\text { the control groups was } \\
151.43\end{array}$ & $\begin{array}{l}\text { The mean self-efficacy score } \\
\text { in the intervention groups } \\
\text { was } 0.47 \text { SD higher }(0.16- \\
0.77 \text { higher })\end{array}$ & $174(3)$ & Moderate $^{e, g}$ & None \\
\hline Skills & $\begin{array}{l}\text { The mean outcome score in } \\
\text { the control groups was } 71\end{array}$ & $\begin{array}{l}\text { The mean skill score in the } \\
\text { intervention groups was } 0.94 \\
\text { SD higher }(0.11-1.77 \text { high- } \\
\text { er) }\end{array}$ & $25(1)$ & Low $\mathrm{d}, \mathrm{e}, \mathrm{f}$ & None \\
\hline
\end{tabular}

\footnotetext{
${ }^{\mathrm{a}}$ The risk in the intervention group (and its $95 \% \mathrm{CI}$ ) is based on the assumed risk in the comparison group and the relative effect of the intervention (and its $95 \% \mathrm{CI}$ ).

${ }^{\mathrm{b}} \mathrm{RCT}$ : randomized controlled trial.

${ }^{\mathrm{c}}$ GRADE: Grading of Recommendations Assessment, Development and Evaluation.

${ }^{\mathrm{d}}$ The heterogeneity was high with large variations in effects and the lack of overlap among CIs.

${ }^{\mathrm{e}}$ Rated down by one level for study limitations. The risk of bias was unclear for allocation concealment in all studies.

${ }^{f}$ Low: Our confidence in the effect estimate is limited. The true effect may be substantially different from the estimate of the effect.

${ }^{g}$ Moderate: We are moderately confident in the effect estimate. The true effect is likely to be close to the estimate of the effect, but there is a possibility that it is substantially different.

\section{Discussion}

In this paper, we systematically reviewed and pooled data on the use of digital education for domestic violence management. We draw attention to the gap in digital education on domestic violence and the potential benefits of this educational strategy. Our findings provide preliminary evidence to show that using

digital education to address socially sensitive issues such as domestic violence may improve certain educational outcomes in health professionals receiving the training. Although competencies, trustable professional activities, knowledge, skills, and attitudes do not automatically translate into change of practice, they are indispensable for improving patient outcomes.
} 
All the studies included in this review were published after the year 2000, which is the period when digital education started becoming more prominent in health care professions' education [51] and more laws were implemented to tackle domestic violence $[5,52,53]$.

Interestingly, we found that in all the studies, the intervention groups had improved knowledge, skills, attitudes, and self-efficacy, even though the studies employed different methodologies, sample sizes, sampling periods, settings, and types of domestic violence education. Additionally, the changes in primary outcomes were observed within short time periods of up to 2 weeks after the intervention, with only one study [43] measuring retention at the 12-month follow-up. Although the variability suggests that digital education has the versatility to reach a wide range of health professionals in different populations and settings, it underscores the potential of homogeneous short-term digital interventions in improving the quality of care that these professionals provide.

Risk of bias was mostly unclear for blinding of outcome assessment and allocation concealment, but it was mainly low for sequence generation. While the nature of the interventions does not allow blinding of participants, we believe it would not have had any effect on bias risk. We minimized biases by having two reviewers independently assess the articles for inclusion, complete data extraction, risk of bias, and use of the GRADE criteria. The overall quality of the evidence was low or moderate due to the risk of bias and inconsistency across the studies (Table 3).

This review has some important strengths including a strict adherence to the gold-standard Cochrane methods and use of validated, comprehensive, and reproducible searches across seven databases. Our review adds to previous research on domestic violence education for health professionals, as it focuses on the use of digital education, which is a growing area of research. Some weaknesses have to be kept in mind when interpreting the results of this systematic review. For instance, although our searches were comprehensive, we cannot be certain that all relevant trials were included.

However, the evidence evaluated has some limitations. First, only a few studies were published in this area, and they were all from high-income countries, making generalizability challenging. Although digital education may potentially serve as an effective and impactful solution to educating health professionals in domestic violence management, applicability, scalability, and implementation in low- and middle-income countries have to be studied further [54]. Second, we acknowledge that in certain countries such as the United Kingdom, social workers are the first "line of response" to domestic violence. Third, only two studies $[47,49]$ measured and reported learners' satisfaction as one of the primary outcomes. This further highlights the need for uniform and validated outcomes and methods of measuring them to make conclusive judgements. Moreover, only two studies [43,47] used validated measurement instruments to measure outcomes, thereby making it challenging to compare the use of digital education between settings. Subsequently, the lack of data on retention rate, costs, or patient outcomes prevents policy makers from making informed decisions or assessing the transferability of digital education to other settings. Finally, none of the RCTs reported secondary outcomes such as patient outcomes, health professionals' behavior change, and economic impact. Hence, we are unable to assess how these outcomes changed with digital education.

Future studies should be designed to evaluate the effect of digital education on these outcomes. We further recommend that future studies consider including other professionals such as social carers, psychologists, counsellors, or teachers. Findings of this review suggest that digital education could contribute to developing the competencies that health professionals need to respond to complex psychosocial problems such as domestic violence. Therefore, future studies should focus on recording more practical outcomes of the trainings such as change in detection and referral rates [55]. This will help ensure a better understanding of the actual value of integrating digital education modules into pre- and postregistration as well as the continuing professional development curricula. In addition, although domestic violence is more accepted and prevalent in low- and middle-income countries, the education gap is wide and digital education is still at the developing stage in these countries [14,56]. Data should be collected beyond geographical regions with inclusion of the cost analysis to obtain a better understanding of the impact and feasibility of integrating electronic learning modules on domestic violence management into the medical curriculum in low- and middle-income countries. We further recommend that future studies be designed with larger, appropriately powered RCTs, in both developed and low- and middle-income countries alike in order to ensure better representation. Researchers could use methods such as the Consolidated Standards of Reporting Trials for Social and Psychological Interventions 2018 (CONSORT-SPI 2018) checklist as guidance to design and report future studies on digital education for domestic violence in order to ensure that the data collected are of high quality and representative [57].

We believe that while digital education could help increase identification of and support to patients experiencing domestic violence, research with study designs incorporating blended learning might hold the highest potential. Such designs would combine the best of digital education, such as smartphones, apps, emails, text messages, and virtual patients, with the best of traditional classroom practices such as personalized contact or feedback, meetings, and discussions.

In conclusion, we found some promising, predominantly low-quality evidence for the effectiveness of digital education on domestic violence. We also highlighted the need for further research evaluating and validating culturally tailored digital education interventions geared toward more holistic management of domestic violence. 


\section{Acknowledgments}

This research was supported by the Nanyang Technological University eLearning grant. This review was conducted in collaboration with the Health Workforce Department of the World Health Organization. We would also like to thank Mr Carl Gornitzki, Ms GunBrit Knutssön, and Mr Klas Moberg from the University Library, Karolinska Institutet, Sweden, for developing the search strategy, and the peer reviewers for their comments.

\section{Authors' Contributions}

JoC and UD conceived the idea for the review. UD wrote the protocol; performed the searches; screened, extracted, analyzed, and synthesized the data; and wrote and revised the drafts. NN screened and extracted the data. RB analyzed the data. PP, NN, $\mathrm{KJ}$, AHYH, GF, JoC, and JaC critically revised the drafts. All authors contributed to writing and reviewing the manuscript.

\section{Conflicts of Interest}

None declared.

\section{Multimedia Appendix 1}

MEDLINE (Ovid) search strategy.

[PDF File (Adobe PDF File), 69KB-Multimedia Appendix 1]

\section{References}

1. Krantz G. Violence against women: a global public health issue!. J Epidemiol Community Health 2002 Apr;56(4):242-243 [FREE Full text] [doi: 10.1136/jech.56.4.242] [Medline: 11896128]

2. Hewins E, DiBella D, Mawla J. Domestic Violence and the Role of the Healthcare Provider: The Value of Educating on Assessment and Intervention Strategies. 2013. URL: https://www.nj.gov/dcf/women/archive/WhitePaper DomesticViolence. pdf [accessed 2019-05-11] [WebCite Cache ID 78HqukOOU]

3. World Health Organization. Responding to Intimate Partner Violence and Sexual Violence Against Women: WHO Clinical and Policy Guidelines 2013. Geneva, Switzerland: WHO Press; 2013. URL: https://apps.who.int/iris/bitstream/handle/ 10665/85240/9789241548595 eng.pdf?sequence=1 [accessed 2019-05-20]

4. GOV.UK. 2018 Oct 05. Guidance - Domestic abuse: how to get help URL: https://www.gov.uk/guidance/ domestic-abuse-how-to-get-help [accessed 2019-05-11] [WebCite Cache ID 78HrLgtRD]

5. Kaur R, Garg S. Addressing domestic violence against women: an unfinished agenda. Indian J Community Med 2008 Apr;33(2):73-76 [FREE Full text] [doi: 10.4103/0970-0218.40871] [Medline: 19967027]

6. World Health Organization. Understanding and addressing violence against women. Intimate partner violence URL: http:/ lapps.who.int/iris/bitstream/handle/10665/77432/WHO RHR 12.36 eng.pdf?sequence=1 [accessed 2018-10-01] [WebCite Cache ID 76UiiccJ9]

7. Florida State University. 2014. Conditions \& Injuries Related to Domestic Violence-National Prevention Toolkit on Domestic Violence for Medical Professionals URL: https://dvmedtraining.csw.fsu.edu/wp-content/uploads/2014/01/ Conditions-and-Injuries-2014.pdf [accessed 2019-05-09] [WebCite Cache ID 78EpIdzHO]

8. Davis R. Domestic violence - related deaths. Jnl Aggress Conflict Peace Res 2010 Apr 14;2(2):44-52. [doi: 10.5042/jacpr.2010.0141]

9. Perona M, Benasayag R, Perelló A, Santos J, Zárate N, Zárate P, et al. Prevalence of functional gastrointestinal disorders in women who report domestic violence to the police. Clin Gastroenterol Hepatol 2005 May;3(5):436-441 [FREE Full text] [Medline: 15880312$]$

10. Stene LE, Jacobsen GW, Dyb G, Tverdal A, Schei B. Intimate partner violence and cardiovascular risk in women: a population-based cohort study. Journal of women's health 2013;22(3):250-258. [Medline: 23428282]

11. Trevillion K, Oram S, Feder G, Howard LM. Experiences of domestic violence and mental disorders: a systematic review and meta-analysis. PLoS One 2012;7(12):e51740. [doi: 10.1371/journal.pone.0051740] [Medline: 23300562]

12. Yut-Lin W, Othman S. Early detection and prevention of domestic violence using the Women Abuse Screening Tool (WAST) in primary health care clinics in Malaysia. Asia Pac J Public Health 2008;20(2):102-116. [doi: 10.1177/1010539507311899] [Medline: 19124304]

13. Usta J, Antoun J, Ambuel B, Khawaja M. Involving the health care system in domestic violence: what women want. Ann Fam Med 2012;10(3):213-220 [FREE Full text] [doi: 10.1370/afm.1336] [Medline: 22585885]

14. Sardinha L, Nájera Catalán HE. Attitudes towards domestic violence in 49 low-middle-income countries: A gendered analysis of prevalencecountry-level correlates. PLOS ONE 2018;13(10):e0206101 [FREE Full text] [Medline: 30379891]

15. Anyangwe SC, Mtonga C. Inequities in the global health workforce: the greatest impediment to health in sub-Saharan Africa. Int J Environ Res Public Health 2007 Jun;4(2):93-100 [FREE Full text] [Medline: 17617671] 
16. Du Plat-Jones J. Domestic violence: the role of health professionals. Nurs Stand 2006;21(14-16):44-48. [doi: 10.7748/ns2006.12.21.14.44.c6392] [Medline: 17252869 ]

17. Arcoraci V, Squadrito F, Altavilla D, Bitto A, Minutoli L, Penna O, et al. Medical simulation in pharmacology learning and retention: A comparison study with traditional teaching in undergraduate medical students. Pharmacol Res Perspect 2019 Feb;7(1):e00449. [doi: 10.1002/prp2.449] [Medline: 30651989]

18. Congdon TW. A medical student's perspective on education about domestic violence. Acad Med 1997 Jan;72(1 Suppl):S7-S9. [Medline: 9008582]

19. Zaher E, Keogh K, Ratnapalan S. Effect of domestic violence trainingystematic review of randomized controlled trials. Canadian Family Physician 2014;60(7):618-624 [FREE Full text] [Medline: 25022633]

20. Runyan CW, Gunther-Mohr C, Orton S, Umble K, Martin SL, Coyne-Beasley T. PREVENT: a program of the National Training Initiative on Injury and Violence Prevention. Am J Prev Med 2005 Dec;29(5 Suppl 2):252-258. [doi:

10.1016/j.amepre.2005.08.013] [Medline: 16376727]

21. Zehry K, Halder N, Theodosiou L. E-Learning in medical education in the United Kingdom. Procedia - Social and Behavioral Sciences 2011;15:3163-3167 [FREE Full text] [doi: 10.1016/j.sbspro.2011.04.265]

22. Shefet D, Dascal-Weichhendler H, Rubin O, Pessach N, Itzik D, Benita S, et al. Domestic violence: a national simulation-based educational program to improve physicians' knowledge, skills and detection rates. Med Teach 2007 Jun;29(5):e133-e138 [FREE Full text] [doi: 10.1080/01421590701452780] [Medline: 17885965]

23. Sangrà A, Vlachopoulos D, Cabrera N. Building an inclusive definition of e-learning: An approach to the conceptual framework. IRRODL 2012 Apr 13;13(2):145-159 [FREE Full text] [doi: 10.19173/irrodl.v13i2.1161]

24. Paul P, Toon E, Hadadgar A, Jirwe M, Lim KTK, Semwal M, et al. PROSPERO CRD42016045571. 2016. Online- and local area network (LAN)-based eLearning interventions for medical doctors' education URL: http://www.crd.york.ac.uk/ PROSPERO/display_record.php?ID=CRD42016045571 [accessed 2019-05-16] [WebCite Cache ID 75r2li0AE]

25. Ruiz JG, Mintzer MJ, Leipzig RM. The impact of E-learning in medical education. Acad Med 2006 Mar;81(3):207-212. [Medline: 16501260$]$

26. Wong WK, Ng PK. An Empirical Study on E-Learning versus Traditional Learning among Electronics Engineering Students. American Journal of Applied Sciences 2016 Jun 01;13(6):836-844 [FREE Full text] [doi: 10.3844/ajassp.2016.836.844]

27. Car J, Carlstedt-Duke J, Tudor Car L, Posadzki P, Whiting P, Zary N, Digital Health Education Collaboration. Digital Education in Health Professions: The Need for Overarching Evidence Synthesis. J Med Internet Res 2019 Dec 14;21(2):e12913 [FREE Full text] [doi: 10.2196/12913] [Medline: 30762583]

28. Kyaw BM, Saxena N, Posadzki P, Vseteckova J, Nikolaou CK, George PP, et al. Virtual Reality for Health Professions Education: Systematic Review and Meta-Analysis by the Digital Health Education Collaboration. J Med Internet Res 2019 Jan 22;21(1):e12959 [FREE Full text] [doi: 10.2196/12959] [Medline: 30668519]

29. Dunleavy G, Nikolaou CK, Nifakos S, Atun R, Law GCY, Tudor Car L. Mobile Digital Education for Health Professions: Systematic Review and Meta-Analysis by the Digital Health Education Collaboration. J Med Internet Res 2019 Feb 12;21(2):e12937 [FREE Full text] [doi: 10.2196/12937] [Medline: 30747711]

30. Huang Z, Semwal M, Lee SY, Tee M, Ong W, Tan WS, et al. Digital Health Professions Education on Diabetes Management: Systematic Review by the Digital Health Education Collaboration. J Med Internet Res 2019 Feb 21;21(2):e12997 [FREE Full text] [doi: 10.2196/12997] [Medline: $\underline{\text { 30789348] }}$

31. George PP, Zhabenko O, Kyaw BM, Antoniou P, Posadzki P, Saxena N, et al. Online Digital Education for Postregistration Training of Medical Doctors: Systematic Review by the Digital Health Education Collaboration. J Med Internet Res 2019 Feb 25;21(2):e13269 [FREE Full text] [doi: 10.2196/13269] [Medline: 30801252]

32. Lall P, Rees R, Law GCY, Dunleavy G, Cotič Z, Car J. Influences on the Implementation of Mobile Learning for Medical and Nursing Education: Qualitative Systematic Review by the Digital Health Education Collaboration. J Med Internet Res 2019 Feb 28;21(2):e12895 [FREE Full text] [doi: 10.2196/12895] [Medline: 30816847]

33. Tudor Car L, Kyaw BM, Dunleavy G, Smart NA, Semwal M, Rotgans JI, et al. Digital Problem-Based Learning in Health Professions: Systematic Review and Meta-Analysis by the Digital Health Education Collaboration. J Med Internet Res 2019 Feb 28;21(2):e12945 [FREE Full text] [doi: 10.2196/12945] [Medline: $\underline{\text { 30816846] }}$

34. Tudor Car L, Kyaw BM, Atun R. The role of eLearning in health management and leadership capacity building in health system: a systematic review. Hum Resour Health 2018 Sep 03;16(44):1-9 [FREE Full text] [doi: 10.1186/s12960-018-0305-9] [Medline: 30176899]

35. Xu X, Posadzki PP, Lee GE, Car J, Smith HE. Digital Education for Health Professions in the Field of Dermatology: A Systematic Review by Digital Health Education Collaboration. Acta Derm Venereol 2018 Oct 15;99(2):133-138 [FREE Full text] [doi: 10.2340/00015555-3068] [Medline: 30320871]

36. Wahabi HA, Esmaeil SA, Bahkali KH, Titi MA, Amer YS, Fayed AA, et al. Medical Doctors' Offline Computer-Assisted Digital Education: Systematic Review by the Digital Health Education Collaboration. J Med Internet Res 2019 Mar 01;21(3):e12998. [doi: 10.2196/12998] [Medline: 30821689]

37. Semwal M, Whiting P, Bajpai R, Bajpai S, Kyaw BM, Tudor Car L. Digital Education for Health Professions on Smoking Cessation Management: Systematic Review by the Digital Health Education Collaboration. J Med Internet Res 2019 Mar 04;21(3):e13000 [FREE Full text] [doi: 10.2196/13000] [Medline: 30829576] 
38. Gentry SV, Gauthier A, L'Estrade Ehrstrom B, Wortley D, Lilienthal A, Tudor Car L, et al. Serious Gaming and Gamification Education in Health Professions: Systematic Review. J Med Internet Res 2019 Mar 28;21(3):e12994 [FREE Full text] [doi: 10.2196/12994] [Medline: 30920375]

39. Kyaw BM, Posadzki P, Dunleavy G, Semwal M, Divakar U, Hervatis V, et al. Offline Digital Education for Medical Students: Systematic Review and Meta-Analysis by the Digital Health Education Collaboration. J Med Internet Res 2019 Mar 25;21(3):e13165. [doi: 10.2196/13165] [Medline: 30907731]

40. Elbourne DR, Altman DG, Higgins JP, Curtin F, Worthington HV, Vail A. Meta-analyses involving cross-over trials: methodological issues. Int J Epidemiol 2002 Feb;31(1):140-149. [Medline: 11914310]

41. Accreditation Council for Continuing Medical Education. CME Content: Definition and Examples URL: https://www. accme.org/accreditation-rules/policies/cme-content-definition-and-examples [accessed 2019-05-10] [WebCite Cache ID 78FzQbEOD]

42. Davis N, Davis D, Bloch R. Continuing medical education: AMEE Education Guide No 35. Med Teach 2008;30(7):652-666. [doi: 10.1080/01421590802108323] [Medline: 18777424]

43. Short LM, Surprenant ZJ, Harris JMJ. A community-based trial of an online intimate partner violence CME program. Am J Prev Med 2006 Feb;30(2):181-185 [FREE Full text] [doi: 10.1016/j.amepre.2005.10.012] [Medline: 16459218$]$

44. Higgins JPT, Green S. Cochrane Handbook for Systematic Reviews of Interventions Version 5.1.0. 2011. URL: http:/ /handbook-5-1.cochrane.org/ [accessed 2019-05-10] [WebCite Cache ID 78FzGlbYZ]

45. Guyatt G, Oxman A, Akl EA, Kunz R, Vist G, Brozek J, et al. GRADE guidelines: 1. Introduction-GRADE evidence profiles and summary of findings tables. J Clin Epidemiol 2011 Apr;64(4):383-394 [FREE Full text] [doi: 10.1016/j.jclinepi.2010.04.026] [Medline: 21195583]

46. Danley D, Gansky S, Chow D, Gerbert B. Preparing dental students to recognize and respond to domestic violence. The Journal of the American Dental Association 2004 Jan;135(1):67-73. [doi: 10.14219/jada.archive.2004.0022]

47. Harris JMJ, Kutob RM, Surprenant ZJ, Maiuro RD, Delate TA. Can Internet-based education improve physician confidence in dealing with domestic violence? Fam Med 2002 Apr;34(4):287-292. [Medline: 12017143]

48. Hsieh NK, Herzig K, Gansky SA, Danley D, Gerbert B. Changing dentists' knowledge, attitudes and behavior regarding domestic violence through an interactive multimedia tutorial. J Am Dent Assoc 2006 May;137(5):596-603. [Medline: $\underline{16739538]}$

49. Shapiro MC, Anderson OR, Lal S. Assessment of a novel module for training dental students in child abuse recognition and reporting. J Dent Educ 2014 Aug;78(8):1167-1175 [FREE Full text] [Medline: 25086150]

50. Smeekens AE, Broekhuijsen-van Henten DM, Sittig JS, Russel IM, ten Cate OT, Turner NM, et al. Successful e-learning programme on the detection of child abuse in emergency departments: a randomised controlled trial. Arch Dis Child 2011 Apr;96(4):330-334. [doi: 10.1136/adc.2010.190801] [Medline: 21233084]

51. Masic I. E-learning as new method of medical education. Acta Inform Med 2008;16(2):102-117 [FREE Full text] [doi: 10.5455/aim.2008.16.102-117] [Medline: 24109154]

52. Neville FG. Preventing violence through changing social norms. In: Oxford Textbook Of Violence Prevention: Epidemiology, Evidence, And Policy. Oxford University Press: Oxford Textbooks In Public Health; 2015:239-244.

53. World Health Organization. World Health Organization. 2009. Violence prevention the evidence: Changing cultural and social norms that support violence URL: https://apps.who.int/iris/bitstream/handle/10665/44147/9789241598330 eng. pdf? sequence $=1 \&$ is Allowed $=y$ [accessed 2019-02-02]

54. World Health Organization. Global and regional estimates of violence against women: Prevalence and health effects of intimate partner violence and non-partner sexual violence. Geneva, Switzerland: WHO; 2013. URL: https://tinyurl.com/ yxjzygor [accessed 2019-02-02] [WebCite Cache ID 78G0cSgNH]

55. Feder G, Davies RA, Baird K, Dunne D, Eldridge S, Griffiths C, et al. Identification and Referral to Improve Safety (IRIS) of women experiencing domestic violence with a primary care training and support programme: a cluster randomised controlled trial. Lancet 2011 Nov 19;378(9805):1788-1795. [doi: 10.1016/S0140-6736(11)61179-3] [Medline: 22000683]

56. Passey D, Laferrière T, Ahmad MYA, Bhowmik M, Gross D, Price J, et al. Educational Digital Technologies in Developing Countries Challenge Third Party Providers. Journal of Educational Technology \& Society 2016;19(3):121-133.

57. Grant S, Mayo-Wilson E, Montgomery P, Macdonald G, Michie S, Hopewell S, on behalf of the CONSORT-SPI Group. CONSORT-SPI 2018 Explanation and Elaboration: guidance for reporting social and psychological intervention trials. Trials 2018 Jul 31;19(1):406 [FREE Full text] [doi: 10.1186/s13063-018-2735-z] [Medline: $\underline{30060763}$ ]

\section{Abbreviations}

CME: Continued Medical Education

CONSORT-SPI: Consolidated Standards of Reporting Trials for Social and Psychological Interventions

DV: domestic violence

GRADE: Grading of Recommendations Assessment, Development and Evaluation

HCP: health care professional

IPV: intimate partner violence 
LG: Lecture Group

RCT: randomized controlled trial

SMD: standardized mean difference

WHO: World Health Organization

Edited by A Marusic; submitted 02.03.19; peer-reviewed by W Turner, T Franic, S Pranic, D Adeloye; comments to author 27.03.19; revised version received 14.04.19; accepted 01.05.19; published 23.05.19

Please cite as:

Divakar U, Nazeha N, Posadzki P, Jarbrink K, Bajpai R, Ho AHY, Campbell J, Feder G, Car J

Digital Education of Health Professionals on the Management of Domestic Violence: Systematic Review and Meta-Analysis by the

Digital Health Education Collaboration

J Med Internet Res 2019;21(5):e13868

URL: http://www.jmir.org/2019/5/e13868/

doi: $10.2196 / 13868$

PMID: 31124462

(CUshashree Divakar, Nuraini Nazeha, Pawel Posadzki, Krister Jarbrink, Ram Bajpai, Andy Hau Yan Ho, James Campbell, Gene Feder, Josip Car. Originally published in the Journal of Medical Internet Research (http://www.jmir.org), 23.05.2019. This is an open-access article distributed under the terms of the Creative Commons Attribution License (https://creativecommons.org/licenses/by/4.0/), which permits unrestricted use, distribution, and reproduction in any medium, provided the original work, first published in the Journal of Medical Internet Research, is properly cited. The complete bibliographic information, a link to the original publication on http://www.jmir.org/, as well as this copyright and license information must be included. 